\title{
Health Care Providers' Knowledge of, Attitudes Toward and Provision of Emergency Contraceptives In Lagos, Nigeria
}

CONTEXT: Emergency contraception can play an important role in reducing the rate of unintended pregnancies in Nigeria. Although it is included in the national family planning guidelines, there is limited awareness of this method among clients.

METHODS: In 2003-2004, a sample of 256 health care providers within Lagos State were surveyed about their knowledge of, attitudes toward and provision of emergency contraceptives, using a 25-item, self-administered questionnaire. Frequencies were calculated for the various measures, and chi-square tests were used to determine significant differences.

RESULTS: Nine in 10 providers had heard of emergency contraception, but many lacked specific knowledge about the method. Only half of them knew the correct time frame for effective use of emergency contraceptive pills, and threefourths knew that the pills prevent pregnancy; more than a third incorrectly believed that they may act as an abortifacient. Fewer than a third of respondents who had heard of the pills knew that they are legal in Nigeria. Of those who had heard about emergency contraception, $58 \%$ had provided clients with emergency contraceptive pills, yet only $10 \%$ of these providers could correctly identify the drug, dose and timing of the first pill in the regimen. Furthermore, fewer than one in 10 of those who knew of emergency contraception said they always provided information to clients, whereas a fourth said they never did so.

CONCLUSIONS: Nigerian health care providers urgently need education about emergency contraception; training programs should target the types of providers who are less knowledgeable about the method.

International Family Planning Perspectives, 2006, 32(2):89-93
ByOlufunke Margaret Ebuehi, Osaretin A. T.

Ebuehi and

Victor Inem

Olufunke Margaret Ebuehi is lecturer and Victor Inem is senior lecturer, Institute of Child Health and Primary Care, and Osaretin Ebuehi is associate professor, Department of Biochemistry-all at the College of Medicine, University of Lagos, Lagos, Nigeria.
Emergency contraceptives can be used after unprotected intercourse to prevent unwanted pregnancy. Several methods are safe and effective, including combined hormonal contraceptives taken in a higher dose than is used for regular contraception (the Yuzpe method), the levonorgestrelonly regimen and insertion of a Copper T IUD. ${ }^{1}$ Emergency contraception prevents pregnancy mainly by inhibiting or delaying ovulation; it cannot interrupt an established pregnancy.

In Nigeria, unintended pregnancy poses a major challenge to the reproductive health of women, particularly young adults. Some young women with unintended pregnancies obtain abortions-many of which are performed under unsafe conditions-and others carry their pregnancies to term, incurring the risk of morbidity and mortality associated with pregnancy and delivery. ${ }^{2}$ Emergency contraceptives could play an important role in averting pregnancies attributable to nonuse or incorrect use of contraceptives, contraceptive failure, lack of knowledge about or access to methods, or coerced sex. Their use could also reduce the rate of unsafe abortion.

The Nigerian government's national family planning guidelines follow those developed by the Planned Parenthood Federation of Nigeria, which include emergency contraceptives; the federation conducts educational and dis- semination activities for the general public and health care providers. Levonorgestrel-only pills (Postinor-2, a dedicated product) and combined oral contraceptives (Lo-Femenal, a regular contraceptive that in high doses can be used for emergency contraception) are the most common products used in Nigeria; they can be obtained over the counter from patent medicine shops and pharmacies. Although the pills are sold over the counter, health care providers play a critical role in informing their clients about emergency contraception, and so it is imperative that providers themselves be well informed about the methods.

According to several studies, fewer than half of Nigerian women who were aware of or had used emergency contraceptives had received information on the method from trained health care providers. ${ }^{3}$ This indicates that many providers may have inadequate knowledge about emergency contraception or may not be effectively conveying relevant information to their clients. Two South African studies reported that some providers expressed concerns about promoting emergency contraception because they felt it could affect the uptake and consistent use of regular contraceptive methods. ${ }^{4}$ There was also concern that emergency contraceptives do not protect against STIs or HIV and that their use could discourage condom use.

This study assesses the knowledge about, attitudes to- 


\begin{tabular}{|c|c|}
\hline Characteristic & $\begin{array}{l}\% \\
(\mathrm{~N}=256)\end{array}$ \\
\hline \multicolumn{2}{|l|}{ Gender } \\
\hline Male & 48.4 \\
\hline Female & 51.6 \\
\hline \multicolumn{2}{|l|}{ Occupation } \\
\hline Physician & 45.3 \\
\hline Nurse & 27.0 \\
\hline Pharmacist & 18.0 \\
\hline Community health worker & 9.8 \\
\hline \multicolumn{2}{|l|}{ Type of facility } \\
\hline Primary health center & 18.4 \\
\hline General hospital & 21.1 \\
\hline Teaching hospital & 32.4 \\
\hline Private hospital & 28.1 \\
\hline \multicolumn{2}{|l|}{ Years of experience } \\
\hline$\leq 10$ & 37.5 \\
\hline $11-20$ & 50.4 \\
\hline $21-30$ & 11.3 \\
\hline$\geq 31$ & 0.8 \\
\hline Total & 100.0 \\
\hline
\end{tabular}

ward and provision of emergency contraceptives among health care providers in Lagos, Nigeria, and offers several strategies for improving access to this method.

\section{METHODS}

Between July 2003 and September 2004, we recruited health care providers at the primary, secondary and tertiary levels of the health care system in Lagos, Nigeria's largest city. To ensure representation of the wide spectrum of trained family planning service providers, we included physicians (in obstetrics and gynecology, community medicine and general practice, from both public and private hospitals), nurses, pharmacists and community health workers. We used four provider lists to generate our original sample: a Nigerian Medical Association list of Lagos-based physicians; a Lagos University Teaching Hospital staff list of physicians, nurses and pharmacists; the member list of the Lagos State branch of the Association of General and Private Medical Practitioners; and a Lagos State Ministry of Health list of community health care providers. A sample of 200 randomly selected providers was obtained for each occupation category, yielding a sampling frame of 800 . Three hundred names were then randomly chosen for the study.

Providers were contacted in person and informed about the study. Of the 300 questionnaires given out, 264 were returned. (Up to four follow-up visits were made to nonrespondents to encourage them to complete questionnaires.) Eight incomplete questionnaires were excluded, yielding a final sample of 256, for an $85 \%$ response rate.

The 25-item, self-administered questionnaire, which had been used in a Brazilian study of obstetrician-gynecologists, ${ }^{5}$ contained both closed- and open-ended questions. After being pretested among 30 Nigerian health care providers who were not participants, the questionnaire was revised for this study. Completed questionnaires were anonymous.

Respondents were asked about their knowledge of, attitudes toward and provision of emergency contraceptives. Knowledge was assessed by a series of questions on the identification of method types and specific medications, and, for emergency contraceptive pills, on the time frame for effective use, mechanisms of action, appropriate candidates for use, indications for use and its legal status. Providers' knowledge was considered "good" if they correctly answered 16 or more of the 19 knowledge questions. Scores of 11-15 were considered "fair" and those of 10 or lower were considered "poor."

To assess respondents' attitudes toward prescribing emergency contraceptives, they were asked how they would counsel an adolescent who had had unprotected sexual intercourse two days earlier and did not want to get pregnant. Possible options were: give advice on how to use emergency contraceptives; prescribe either Postinor-2 or a high dose of combined oral contraceptives; insert a Copper T IUD; do nothing because of personal opposition to the method; and give the adolescent a serious reprimand and tell her to return later for contraceptives if she does not get pregnant.

Respondents also answered a series of questions about their provision of emergency contraception, including whether they had ever prescribed it, the method prescribed, indications for prescription, the recommended regimen (pill identification, dose and timing) and the situations in which they gave information to clients.

Frequency measures were computed for all quantitative variables, and frequency distributions were generated for categorical variables. Chi-square tests were used for the comparison of proportions and for examining the association between categorical variables in contingency tables. Associations and differences were considered statistically significant at $\mathrm{p} \leq .05$. Data were coded and analyzed using Epi Info version 6.04 .

\section{RESULTS}

Forty-eight percent of respondents were male and $52 \%$ were female (Table 1). Nearly half were doctors, about a quarter were nurses, and the rest were pharmacists and community health workers. Most respondents worked in government hospitals or centers (18\% in primary health centers, $21 \%$ in general hospitals and $32 \%$ in teaching hospitals); $28 \%$ worked at private hospitals. Nearly two-thirds had at least 11 years of work experience.

\section{Knowledge and Attitudes About Emergency Contraception}

Overall, most of the respondents (87\%) had heard about emergency contraceptives, including $97 \%$ of physicians, $81 \%$ of nurses, $89 \%$ of pharmacists and $52 \%$ of community health workers (Table 2). The most common sources of information cited were lectures and family planning workshops and seminars (not shown).

Of the providers who knew about emergency contraceptives, the majority correctly identified methods (82\%) and specific drugs (77\%) from given lists (not shown). How- 
TABLE 2. Percentage of health care providers, by knowledge
of emergency contraceptives and their appropriate use

Characteristic \%

$(\mathrm{N}=223)$

Had heard about emergency contraceptives*

All occupations $\quad 87.1$

Physicians $\quad 97.4$

Nurses $\quad 81.2$

Pharmacists $\quad 89.1$

Community health workers $\quad 52.0$

Identification of method type

Combined pill

Estrogen-only pillt $\quad 32.3$

Copper TIUD 19.3

Monthly injectablet $\quad 11.2$

Trimonthly injectable

Other

0.8

Identification of pill

Combined pill

Postinor-2

65.0

Menstrogent

Gynaecosid +

Don't know

Time for effective use

$\leq 72 \mathrm{hrs}$. after unprotected intercourse $\quad 49.8$

$\leq 24 \mathrm{hrs}$. after unprotected intercourse $\quad 44.4$

After missed period $\quad 5.4$

During menstrual period $\quad 2.2$

Don't know

2.7

Action of pills

Prevent pregnancy $\quad 48.8$

Induce abortion $\quad 12.6$

Prevent pregnancy and induce abortion $\quad 26.0$

Don't know $\quad 12.6$

Appropriate candidates for use

Women who have had unprotected sex $\quad 78.9$

Inconsistent contraceptive users $\quad 61.0$

Women who have infrequent sex $\quad 48.4$

Adolescents $\quad 31.8$

Women with multiple partners $\quad 25.1$

Perimenopausal women $\quad 22.0$

Others $\quad 2.7$

Don't know $\quad 8.1$

Indications for use

Rape $\quad 86.1$

Unprotected intercourse $\quad 79.8$

Condom breakage $\quad 76.1$

Missed pills $\quad 57.4$

Infrequent sex $\quad 40.8$

Don't know $\quad 0.9$

${ }^{*} \mathrm{~N}=256$. + Cannot be used for emergency contraception. Note: Respondents could choose more than one answer for all knowledge questions except mechanism of action.

ever, large proportions of respondents selected methods and pills that are not emergency contraceptives.

Half of the respondents correctly answered that emergency contraceptive pills could be taken up to 72 hours after unprotected intercourse. More than four in 10, however, believed that they were effective only within 24 hours of unprotected sex. Half of the providers correctly indicated that the pills prevent pregnancy; $13 \%$ incorrectly believed that they induce abortion, and 26\% believed that they both prevent pregnancy and induce abortion. Another 13\% said they did not know.
When asked to identify appropriate candidates for using emergency contraceptives, providers cited women who have had unprotected intercourse (79\%), inconsistent contraceptive users (61\%), women who have infrequent sex (48\%), adolescents (32\%), women with multiple partners (25\%) and perimenopausal women (22\%). Respondents identified the following situations in which the method would be appropriate: in cases of rape (86\%), after unprotected intercourse (80\%), following condom breakage (76\%), after missing regular contraceptive pills (57\%) and following infrequent intercourse (41\%).

A majority of providers who had heard about emergency contraceptives said they would give advice on how to use them (62\%), while 43\% would prescribe either a high dose of combined oral contraceptives or Postinor-2 (not shown). Of those who were legally permitted to insert Copper T IUDs (152), 26\% indicated that they would do so. Fifteen percent of those who knew about emergency contraception would give the woman a serious reprimand and tell her to come back for contraceptives if she did not get pregnant, and 6\% said they would do nothing because they were opposed to abortion.

Nearly three in 10 knew that emergency contraceptives were legal and included in the national family planning guidelines. Fifty-five percent did not know the legal status of emergency contraception, 16\% believed it was legal but not in the guidelines and 4\% thought it was illegal.

Overall, among respondents who had heard about emergency contraception, only $24 \%$ had good knowledge, 59\% had fair knowledge and 17\% had poor knowledge. The level of knowledge differed by occupation, with a higher proportion of physicians having good knowledge (35\%), followed by community health workers (23\%), pharmacists $(15 \%)$ and nurses $(9 \%$; $<.001)$. By medical specialty, obstetrician-gynecologists and community health physicians scored the highest on this measure $(42 \%$ and $56 \%$, respectively), with primary health care specialists, private general practitioners and midwives scoring significantly lower (5-24\%; p<.001). There was no significant association between having good knowledge of the method and either years of experience or type of facility where respondents worked.

\section{Provision of Emergency Contraceptives}

Of the providers who had heard about emergency contraceptives, 58\% had prescribed a method. Among these, all had prescribed hormonal pills, and fewer than one in 10 had provided Copper T IUDs (Table 3-page 92). Nearly all of these providers had prescribed emergency contraceptives to women who had had unprotected intercourse, and two-thirds had done so for rape victims; one-third had prescribed them for women who had missed regular contraceptive pills.

Only 10\% of those who had provided the pills identified the name, dose and timing of the first pill correctly for either the Yuzpe or Postinor-2 regimen, and just two in 10 were able to give the correct name and dose. Nearly six in 


\begin{tabular}{|c|c|}
\hline Characteristic & $\begin{array}{l}\% \\
(\mathrm{~N}=129)\end{array}$ \\
\hline \multicolumn{2}{|l|}{ Method prescribed } \\
\hline Hormonal pill & 100.0 \\
\hline Copper TIUD & 7.0 \\
\hline \multicolumn{2}{|l|}{ Indications for prescription } \\
\hline Unprotected intercourse & 93.8 \\
\hline Rape & 67.4 \\
\hline Missed pills & 32.6 \\
\hline Other & 12.4 \\
\hline \multicolumn{2}{|l|}{ Description of regimen prescribed } \\
\hline Only name of pill was correct & 58.9 \\
\hline Only name and dose were correct & 19.4 \\
\hline Name, dose and timing of first pill were correct & 10.1 \\
\hline Completely incorrect & 8.5 \\
\hline None & 3.1 \\
\hline
\end{tabular}

10 gave the correct name only. Half of the physicians in obstetrics and gynecology who had prescribed the pills correctly identified the name, dose and timing, whereas a fourth of prescribing general practitioners and community health physicians did so (not shown).

Among respondents who had heard about emergency contraceptives, fewer than one in 10 said they always provided information to clients, while one-fourth never informed clients. Nearly two-thirds said they gave information occasionally or only on request.

\section{DISCUSSION}

The study revealed a high degree of awareness of and a largely favorable disposition toward emergency contraceptives among health care providers in Lagos. However, our findings showed a dearth of specific knowledge of the time frame for effective use, mechanism of action, legal status and correct prescription of emergency contraceptive pills. These findings are similar to those of other studies. ${ }^{6}$

As expected, physicians demonstrated better knowledge and reported more frequent provision of the method than nurses, pharmacists and community health workers. Hence, training programs on emergency contraception should target these other groups, especially because they constitute the majority of family planning service providers. Such training could be incorporated into medical and nursing curricula, and periodic refresher sessions could be offered to those who are directly involved in family planning services. Health care providers in Nigeria clearly need more information on all aspects of emergency contraception. These educational efforts should focus on providing specific knowledge, with special attention to correcting common misconceptions about the method. Providers should be encouraged to inform all potential users about the method and to prescribe it to clients who require it. Communication about emergency contraception would also provide opportunities for counseling on long-term contraceptive needs.

Effective educational interventions are likely to improve providers' knowledge and subsequent provision of the method. Emergency contraception has considerable potential to prevent unintended pregnancies, particularly among adolescents and young adults, who constitute the vast majority of the sexually active population.

\section{REFERENCES}

1. Berer $\mathrm{M}$ et al., Consensus statement on emergency contraception, Contraception, 1995, 52(4):211-213.

2. Harrison KA et al., The influence of maternal age and parity on childbearing with special reference to primigravidae aged 15 years and under, British Journal of Obstetrics and Gynaecology, 1985, 5(Suppl.):23-31.

3. Aziken ME et al., Knowledge and perception of emergency contraception among female Nigerian students, International Family Planning Perspectives, 2003, 29(2):84-87; and Ebuehi OM et al., Knowledge and practice of emergency contraception among female undergraduates of the University of Lagos, East African Medical Journal, 2006, 83(3):20-25.

4. McFadyen L et al., Expanding Contraceptive Choice: An African Study of Emergency Contraception, Durban, South Africa: Reproductive Health Research Unit, University of the Witwatersrand, 2003, pp. 6-10; and Blanchard K, Harrison T and Sello M, Pharmacists' knowledge and perceptions of emergency contraceptive pills in Soweto and the Johannesburg Central Business District, South Africa, International Family Planning Perspectives, 2005, 31(4):172-178

5. Loren G et al., Emergency contraception: knowledge, attitudes and practices among Brazilian obstetrician-gynecologists, International Family Planning Perspectives, 1999, 25(4):168-171.

6. McFadyen L et al., 2003, op. cit. (see reference 4); Blanchard K, Harrison T and Sello M, 2005, op. cit. (see reference 4); and Loren G et al., 1999, op. cit. (see reference 5).

\section{RESUMEN}

Contexto: La anticoncepción de emergencia puede desempenar un importante papel en la reducción de la tasa de embarazos no planeados en Nigeria. Si bien el método está incluido en las directrices nacionales en materia de planificación familiar, las clientas tienen un conocimiento muy limitado sobre ello.

Métodos: En 2003-2004, se realizó una encuesta basada en una muestra de 256 proveedores de atención de la salud del Estado de Lagos, para conocer su nivel de conocimiento y actitudes sobre los anticonceptivos de emergencia y su suministro, mediante el uso de un cuestionario autoadministrado que constó de 25 puntos. Se calcularon las frecuencias para las diversas medidas y se utilizaron pruebas de chi-cuadrado para determinar las diferencias significativas.

Resultados: Nueve de 10 proveedores habían oído hablar sobre la anticoncepción de emergencia, pero muchos no tenían un conocimiento específico acerca del método. Solamente la mitad de ellos conocían con certeza sobre los plazos para el uso efectivo de estas pildoras, y las tres cuartas partes sabian que este anticonceptivo previene el embarazo; más de un tercio creía erróneamente que este método podría funcionar como un abortífero. Menos de un tercio de los encuestados que habían oído alguna vez sobre las pildoras sabían que éstas eran legales en Nigeria. De aquellos que habían oído hablar sobre los anticonceptivos de emergencia, el 58\% habian suministrado a sus clientas las píldoras anticonceptivas de emergencia, aunque sólo el 10\% de estos proveedores podían identificar correctamente el medicamento, la dosis y cuándo la mujer debe tomar la primera píldora del tratamiento. Además, menos de uno de cada 
10 de los que conocían la anticoncepción de emergencia indicaron que siempre brindaban información a sus clientas, en tanto que un cuarto indicó que nunca lo habían hecho.

Conclusiones: Los proveedores de servicios de salud de Nigeria tienen una ingente necesidad de ser instruidos en materia de anticoncepción de emergencia; los programas de capacitación deberían concentrar la atención en los proveedores que tienen menos conocimientos sobre este método.

\section{RÉSUMÉ}

Contexte: La contraception d'urgence peut jouer un rôle important dans la réduction des taux de grossesses non planifiées au Nigeria. Bien qu'incluse dans les directives nationales de planification familiale, la méthode n'est guère reconnue parmi les clientes.

Méthodes: En 2003-2004, un échantillon de 256 prestataires de soins de santé de l'état de Lagos a été invité à répondre à un questionnaire de 25 items auto-administré sur ses connaissances des contraceptifs d'urgence, ses attitudes à leur égard et son offre de la méthode. Les fréquences ont été calculées pour les différentes mesures et les différences significatives ont été déterminées par tests chi carré.
Résultats: Neuf prestataires sur 10 avaient entendu parler des contraceptifs d'urgence, mais beaucoup ne possédaient guère de connaissances précises sur la méthode. La moitié seulement connaissaient le délai correct d'usage efficace des pilules contraceptives d'urgence et trois quarts savaient qu'elles ont pour rôle d'empêcher la grossesse; plus du tiers leur ont attribué, par méprise, la fonction d'abortif. Moins du tiers des répondants qui avaient entendu parler de ces pilules savaient qu'elles étaient légales au Nigeria. De ceux qui avaient entendu parler de la contraception d'urgence, 58\% avaient prescrit les pilules à leurs clientes, mais 10\% seulement d'entre eux pouvaient identifier correctement le médicament, la dose et le moment de la première pilule du régime. Moins de 10\% des prestataires au courant de la contraception d'urgence ont du reste déclaré qu'ils en présentaient toujours l'information à leurs clientes, tandis qu'un quart ne le faisaient jamais.

Conclusions: Il existe un besoin urgent d'éducation des prestataires nigérians de la santé au sujet de la contraception d'urgence. Les programmes de formation doivent cibler les types de prestataires les moins informés de la méthode.

Author contact: funkebuehi@yahoo.co.uk

\section{CORRECTION}

The Spanish abstracts for research articles published in the March issue of the journal had not been finalized. The correct versions have now been posted with their respective articles on the Guttmacher Web site, at http://www. guttmacher.org/journals/toc/ifpp3201 toc. html. 